\title{
О.Г. Левашова
}

\section{«...Глаголом жги сердца людей!» (Миф о творце и творчестве в прозе В.М. Шукшина и традиции русской классики)}

Дж. Гивенс недаром называет Шукшина «культурным аутсайдером», тем самым подчеркивая его особое положение в литературе 1960-70-х годов. Свое первое появление на страницах «толстых» литературных журналов Шукшин воспроизводит вполне литературно, в духе героя Дж. Лондона, Мартина Идена, - рассылая в разные редакции «веером» свои рассказы, по настоянию М. Ромма, а в случае отказа меняя их местами. И в дальнейшем творческое становление писателя во многом будет ориентировано на те или иные культурные образцы, прежде всего на традиции русской классики.

Шукшин, поднимаясь к вершинам мастерства, на протяжении всей жизни пытается понять «загадку» творчества. Уже в раннем своем рассказе «Воскресная тоска» он задается вопросом: «А что я такое знаю, чего не знают другие, и что дает мне право р а с с к а 3 ы в а т ь?» [Шукшин, 1992, с. 81. Далее цитирую по этому изданию в самом тексте статьи с указанием тома (римскими цифрами) и страниц (арабскими)]. А.С. Куляпин, обращаясь к анализу «В воскресенье матьстарушка...», видит в нем полемику с пушкинской концепцией творчества, выраженной в стихотворении «Поэт» («Пока не требует поэта...»). В целом ряде произведений («Стенька Разин», «Мастер», «Пьедестал», «цикл» театральных рассказов) Шукшин продолжит свои рассуждения о судьбе и предназначении писателя. На наш взгляд, в художественном творчестве автора «Стеньки Разина» во многом возобладало эпохальное «звучание» темы - трагедия «недовоплотившегося» творца, нереализованного дела мастера, ненаписанного шедевра. Непонят и отвержен истинный творец, торжествует конъюнктурное искусство. В этом смысле сюжет рассказа «Мастер» оказывается «макросюжетом» творчества Шукшина: столярсамородок Семка Рысь смог бы сделать то же, что и великие мастера прошлого, но его путешествие к сильным мира сего за разрешением реставрировать Талицкую церковь оказывается сродни бессмысленному странствию Ивана из повестисказки «До третьих петухов».

Однако, как свидетельствует судьба шукшинского наследия, позитивное решение проблемы творчества было найдено в границах того единого романа, который писатель, по мысли Шукшина, создает всю жизнь и в котором наиболее полно воплощается образ автора, его творческая лаборатория, особенности эстетики и поэтики. В условиях развития единственно возможного художественного метода, соцреализма, ориентация на русскую классику означала поиск своего особого места в литературе.

Интересен тот факт, что современники, осмысляя неповторимость Шукшина, порой обращались к агиографической традиции: В. Распутин видел в позиции автора «Калины красной» поистине «аввакумовскую страсть», Г. Бурков подчеркивал в Шукшине возможность при других обстоятельствах стать «духовником».

Значительно, что Шукшин, будучи не только актером, режиссером, писателем, но и талантливейшим читателем, на протяжении всей своей творческой биографии пытается идентифицировать себя, часто на уровне игрового кода, через 
факты культуры. В последние годы жизни наиболее ощутим его интерес к проблеме личности и творческой лаборатории Достоевского. Такие признания, которые делает Шукшин в своих «Рабочих записях», прямо отсылают к личности выдающегося писателя-классика: «Каждый настоящий писатель, конечно же, психолог, но сам больной» [Шукшин, 1991, с. 466].

Автор «Калины красной» тщательно готовился к своей, может быть, главной роли, стремясь сыграть Достоевского. Е. Громов пишет о неизгладимом впечатлении, производимом Шукшиным в гриме Достоевского: «Сохранились фотографии, актерская проба, - Шукшин в гриме Достоевского. Впечатление потрясающее! Оставаясь вполне узнаваемым, Шукшин вместе с тем всецело сливается с Достоевским...» [Громов, 1979, с. 18]. Рассуждая о портретах Л. Толстого, В.В. Розанов видит в них «коренное русское лицо, доведенное до апогея выразительности и силы», «нашу родную деревню» [Розанов, 1995, с. 27].

Однако в Шукшине более отозвался лик по преимуществу петербургского писателя, в страдальческих чертах которого запечатлелся образ «больного» города. Особенности психологического склада Достоевского и Шукшина свидетельствуют о невротическом характере личности. В воспоминаниях о них возникает облик нелюдимого, необщительного, очень ранимого человека. Такими они представали в обществе «чужих». Для обоих характерен комплекс «белой вороны». А. Заболоцкий, имевший возможность долгое время наблюдать Шукшина в период съемок двух шукшинских фильмов, говорит о его полном одиночестве. В своей книге «Шукшин в кадре и за кадром» он приводит следующее рассуждение актера Саранцева, близко знавшего Шукшина в годы учебы во ВГИКе: «Соврешенно ясно, что во ВГИКе с первого курса, а может, еще и с абитуриентских ступенек этого учебного заведения, конфликт Шукшина обострился окончательно, стал социально и этически вполне им осознанным... Вне этого конфликта с окружением нет Шукшина. Писателя. Режиссера. Актера...» (Цит. по кн.: [Заболоцкий, 1997, c. 10]). О сложности характера Достоевского, о его одиночестве, о непонимании, о постоянном конфликте с окружением пишут почти все мемуаристы. А.Г. Сниткина, отправляясь на первую встречу с Достоевским, услышала от своего учителя стенографии следующую нелестную характеристику писателя: «Это чрезвычайно угрюмый господин, ужасно мрачный, я решительно не знаю, как вы с ним сойдетесь» [Ф.М. Достоевский в воспоминаниях современников, 1990, с. 102]. В.В. Тимофеева (О. Починковская), корректор, долгое время работавшая с Достоевским, отмечает, что писатель «страдал своим духовным одиночеством, тем, что его не понимали и перетолковывали...» [Там же, с. 180]. Этим во многом объясняется сложное отношение обоих писателей к миру, к себе, к «другому». При близком знакомстве с их прозой и воспоминаниями современников о Достоевском и Шукшине, бросается в глаза общая черта - от читателя ускользает определенность авторского «я», подключается намеренно игровой «код». Л. Толстой (биографический автор) оказывается более соотносимым со своим автопсихологическим героем.

До сих пор «достоеведы» вопрошают: кто он, автор «Бесов» и «Братьев Карамазовых», - бунтарь Иван, демон Ставрогин или ранний человеколюбец Алеша? И Шукшин, став столичным интеллигентом, поднявшись до высот мировой культуры, выстраивает «миф» о «человеке в кирзовых сапогах». Д.С. Мережковский также в действиях позднего Толстого усматривает неискренность в «переодевании» писателя в посконную рубаху, «игровое поведение» [Мережковский, 1995, с. 7]. Однако в мучительных поисках позднего Толстого, в его трагической раздвоенности, которую отразил и его герой, трудно усмотреть элементы «игры». Здесь та и другая часть психологического облика автора и героя «взаправду» и всерьез.

Отсутствие устойчивой психологической авторской идентификации все же в 
большей мере свойственно Достоевскому и Шукшину и приводит к сложному характеру автобиографизма в их творчестве, подвижности границ между «я» и «нея». На этом основании Б.И. Бурсов считает, что Достоевский «разменивает свою единственную душу на десятки, а то и сотни чужих душ, а с другой - как бы присваивает эти последние себе самому, как лично ему принадлежащие, отчего так безмерно, в нашем представлении, да и на самом деле, разрастается его первозданная, единичная, так поражающая нас своими размерами душа» [Бурсов, 1974, c. 610]. Споры в критике о героях Шукшина, диаметрально противоположные их характеристики свидетельствуют не только и не столько о непроясненности авторской позиции, скорее, это результат сложного синтеза «своего» и «чужого». Внешнее сходство Достоевского и Шукшина, особенно ощутимое и почувствованное писателем, режиссером и актером в 1970-е годы, таит определенную и большую, чем в случае с Толстым, психологическую общность, которая, на наш взгляд, сказалась в наличии сходных черт мировоззрения и творческой лаборатории. По мнению Г. Горышина, общность писателей разных историколитературных эпох неслучайно открылась автору романа-исследования «Личность Достоевского» Б.И. Бурсову, который мечтал о встрече с Шукшиным и не успел встретиться. Автор статьи «Где-нибудь на Руси...» замечает: «Бурсова с Шукшиным сблизил Федор Михайлович Достоевский, будучи близок - каждому на свой манер - двум этим столь различным по возрасту, по жизненному опыту и сфере применения сил литераторам» [Горышин, 1975, с. 26].

Шукшин свое творческое кредо выразил в рабочих записях словами А.С. Пушкина: «Восстань, пророк, и виждь, и внемли... Глаголом жги сердца людей!» [Шукшин, 1991, с. 466]. Известно, что именно Пушкин, прежде всего стихотворением «Пророк», задал новый импульс бытования в русской литературе мифа о творце. Вся дальнейшая литературная традиция либо следовала, либо опровергала этот пушкинский эстетический постулат. Более того, отношение к Пушкину в истории русской культуры было во многом определяющим для поиска писателем своего места в литературном процессе, художественного метода, эстетики и поэтики.

Раннее творчество Шукшина характеризуется наличием типологических связей с эстетикой Пушкина и Л. Толстого. Общность выявится тезисом: «Чем ближе к искусству, тем фальшивее». Эта особенность ярче всего выступает в ранних «театральных» рассказах и рассказах об искусстве Шукшина («Крыша над головой», «Артист Федор Грай», «Критики», «Ваня, ты как здесь?!»). Отголоски этой концепции ощутимы и в 1970-е г. С. Бондарчук вспоминал: «Однажды мы смотрели материал его картины («Калина красная» - О.Л.), и я в качестве одобрения сказал ему: «Это искусство». Но Шукшина до крайности обидело слово. Оно звучало для него как уход от жизни, а этого он не мог терпеть, всегда и во всем добиваясь подлинности» [Бондарчук, 1979, с. 193]. Созвучным Толстому оказывается шукшинское представление об отношении художника к жизни. Шукшин, характеризуя художественное творчество, писал: «Жизнь представляется мне бесконечной студенистой массой - теплое желе, пронизанное миллиардами кровеносных переплетений, нервных прожилок... Беспрестанно вздрагивающее, пульсирующее, колыхающееся. $<\ldots>$...если погрузиться всему в эту животворную массу, - немедленно начнешь - с ней вместе - вздрагивать, пульсировать, вспучиваться и переворачиваться. И умрешь там» [Шукшин, 1991, с. 466-467]. Данный образ, несомненно, вызывает в памяти сон-бред Пьера в плену, его видение водяного шара, состоящего из отдельных капель, являющийся некой микромоделью всего романа-эпопеи Л. Толстого «Война и мир», пластическим воплощением «роевого» начала, символом толстовской «живой жизни».

Однако в поздней прозе автора «Точки зрения» и повести-сказки «До третьих петухов» явно ощутимы и другие тенденции. 
Толстой даже в ранний период, создавая повести и рассказы, ощущал себя писателем большого эпического дыхания, о чем свидетельствуют его первые замыслы. Автор «Войны и мира» и «Анны Карениной» для Шукшина всегда являлся знаком «большой литературы» и мастерства. Однако тема мастера звучит в шукшинском творчестве и в игровом ключе («...Умел закручивать граф Толстой, а? Мастер, мастер. Биография только... того, а так - мастер» - «Точка зрения» (III, 445). Эстетическая позиция писателей разных историко-литературных эпох выявляется прежде всего относительно к Пушкину. Известно, что Толстой на протяжении своего творчества менял взгляд на пушкинскую прозу в зависимости от тех художественных задач, которые решал сам. Достоевскому и Шукшину оказалась близка пушкинская концепция творчества, выраженная поэтом в стихотворении «Пророк». Пророческий дар и служение людям - две составляющие, которые характеризуют, по мнению Достоевского и Шукшина, истинное искусство. Ю. Селезнев в своей книге «В мире Достоевского», ссылаясь на мемуары современников, подчеркивает значительность «Пророка» А.С. Пушкина для творческого самоопределения писателя. По воспоминаниям Варвары Васильевны Тимофеевой (выступавшей как писательница под фамилией О. Починковская), Достоевский, рассказывая о страшных минутах перед смертной казнью, вдохновенно читал пушкинского «Пророка» [Ф.М. Достоевский в воспоминаниях современников, 1990 , с. 21].

Концепция творчества, выраженная пушкинскими строками, объясняется особым отношением писателей к разным формам художественного времени. Известно, что Достоевский, высоко ценивший эпический дар Л. Толстого, все же считал его художником, который по преимуществу изображает прошлое в его сложившихся, законченных формах. Главную особенность своего творчества автор «Дневника писателя» видит в «тоске по текущему», более того, не обижаясь на современников, Достоевский не устает повторять, что пишет для будущего. Для изображения лишь складывающейся на глазах действительности, в условиях «переворотившегося» мира, писателю необходим был пророческий дар. Но и Шукшину свойственна «тоска по настоящему». Основная цель творчества автора «Калины красной» - «Важно прорваться в будущую Россию» [Шукшин, 1991, с. 463] - выглядит «образом-рифмой» к одному из важнейших программных заявлений писателя-классика. Поэтому модель художественного времени Л. Толстого можно представить как настоящее, имеющее тенденцию возвращения в прошлое, с целью обнаружения причинно-следственных связей, нагляднее всего эта модель выступает в истории создания «Войны и мира», сюжетного движения от замысла «Декабристов» до романа-эпопеи. Для Достоевского и Шукшина, настоящее - опора для постижения будущего. Поэтому творчество писателей разных историколитературных эпох лишено черт стабильности. В. Соловьев, характеризуя художественный мир Достоевского, писал: «Здесь все в брожении, ничего не установилось, все еще только становится...». И далее, определяя предмет изображения, философ находит емкую формулу - «общественное движение» [О Достоевском. Творчество Достоевского в русской мысли 1881-1931 годов, 1990, с. 36]. Образ «сдвинувшегося мира» характерен и для творчества писателя ХХ в.

Поэтому возникает необходимость торопиться схватить, запечатлеть быструю смену современных событий. «Каторга» работы, суетность жизни становятся неотъемлемой чертой художественного дара писателей. «Работа измучила меня нравственно и физически; чувствую себя даже нездоровым...», - признается Достоевский (С.А. Ивановой 6 (18) января 1871 г.) [Достоевский, 1986, с. 163. Далее цитирую по этому изданию в самом тексте работы с указанием тома (римскими цифрами) и страниц (арабскими)]. Не менее мучительно работал и Шукшин. В «Рабочих записях» характерно самопризнание: «Никогда, ни разу в своей жизни я не позволил себе пожить расслабленно, развалившись. Вечно напряжен и собран. 
И хорошо, и плохо. Хорошо - не позволил сшибить себя; плохо - начинаю дергаться, сплю с зажатыми кулаками... Это может плохо кончиться, могу треснуть от напряжения» [Шукшин, 1991, с. 464]. У Достоевского в поздний период часто встречается утверждение, что в каторге было вольготнее: «Сижу над работой как каторжник...» (А.Е. Врангелю, 18 февраля 1866 (XXVIII (II), 150)). Не менее характерно и шукшинское сопоставление: «Я, как пахарь, прилаживаюсь к своему столу, закуриваю - начинаю работать» [Там же, с. 464].

В.И. Коробов проводит явную аналогию между творческой лабораторией Достоевского и Шукшина: «Рукописи Шукшина не пестрят бесконечными поправками, исправлениями, вставками, но полагать, что это потому, дескать, что он спешил и времени «на отделку» и «филигрань» у него не было, работал топором и т.п., - наивно. Все это очень старая песня, похожая, кстати, на ту, что «пелась» десятки лет о Достоевском: спешил из-за нужды, не отделывал, портил. Но, как убедительно доказал недавно Юрий Селезнев в своей книге «В мире Достоевского», тут больше спешили и портили холодные ученые исследования, а почти все «неправильности» стиля Достоевского - глубоко выстраданные и выношенные художником особенности. Вот и с «недоделками» Шукшина примерно та же картина» [Селезнев, 1980, с. 217]. Не только работы о «небрежении словом» в творчестве Достоевского [Лихачев, 1976, с. 30-41], но и установка Шукшина на все богатство разговорной устной речи свидетельствовали о поисках писателями новой образности. В.Е. Ветловская, исследуя стилистические особенности последнего романа Достоевского, находит в нем «нарушения в употреблении слова, грамматические, логические, эстетические», «неловкие» и «неуклюжие» фразы. В таком использовании слова исследователь усматривает особую функцию - создание неожиданности высказывания, подчеркивание взволнованности говорящего, импровизационного характера речи героя. На фоне нейтрального, стертого слова «неловкая фраза, по мысли В.Е. Ветловской, обладает всеми преимуществами слова в грамматически неправильной конструкции: оно выделяет, задерживает внимание...» [Ветловская, 1977, с. 37]. «Неправильная» речь шукшинского рассказчика и героев отвечает тем же требованиям и выполняет сходную эстетическую задачу.

Существенные «переклички» обнаруживаются в отношении к слову Достоевского и Шукшина. Д.С. Мережковский в своей книге делает интересное замечание о важности оппозиции «видеть» и «слышать» в творчестве Толстого и Достоевского, которая воплощает описательный характер художественного дара Толстого и иное, преимущественное отношение к слову Достоевского. М.М. Бахтин уже в первом романе писателя «Бедные люди», анализируя «коперниковский переворот», который произвел Достоевский в литературе, связывает его с тем, что слово становится главным предметом изображения. У писателя XX в. сходное отношение к звучащему слову. В этом аспекте знаменательным становится факт использования Н. Лейдерманом в характеристике шукшинского повествователя слова, введенного в художественный оборот Достоевским. Речь идет о глаголе «стушеваться»: «Но он не «выступает», а как бы «стушевывается», чтоб не отвлекать на себя внимание от ядра рассказа - от диалога, в котором бьется, утверждая и отвергая, падая и воспаряя, <..> мысль человеческая, мучительно ищущая истину бытия» [Лейдерман, 1982 a, с. 55]. Не только «словечко» обнаруживает связь с точным контекстом предшествующей культуры, но и пафос самого высказывания исследователя.

Л. Геллер в анализе рассказа «Срезал» специально останавливается на языке главного героя и выводит во многом универсальную формулу шукшинского языка, которая заключается в том, что крестьянин «свой язык потерял, а чужому не научился» [Геллер, 1979, с. 115]. Языковая ситуация, воссозданная в произведениях писателя, отражает эпохальные процессы и, с одной стороны, воплощает характер героя-«недогматика», не посаженного на науку поведения, с другой, изо- 
бражает «героя времени» - «демагога». Толстовский герой, как правило, человек «догмы», при всей своей «текучести». Часто, как и автор, он живет соответственно написанным программам, кодексу чести, внутренним нравственным установкам, с которыми соотносим. У Достоевского и Шукшина преимущественный интерес к слову обусловлен особым типом героя-маргинала. Т.И. Печерская, характеризуя этот человеческий тип, пишет о том, что язык становится для героя важнейшим «инструментом» самопознания и самоидентификации: «Ощущение инаковости ясознания в сравнении со всяким другим заметно активизирует поиски адекватного языка его описания, при этом предметом рефлексии становится и собственное критическое усилие, и собственная языковая обусловленность» [Печерская, 1999, c. 60]. Поэтому программными являются рассуждения Шукшина о прямой речи, это не только конструктивный, но и концептуальный признак его антропоцентрического мира: «Прямая речь позволяет мне крепко поубавить описательную часть: какой человек? Как он думает? Чего хочет? В конце концов, мы ведь так и составляем понятие о человеке - послушаешь его. Тут он не соврет - не сумеет, даже если захочет» [Шукшин, 1991, с. 370]. Одним из главных критериев удачного рассказа для автора «Калины красной» станут «живые голоса людей», которые писатель «как будто пером вытаскивает из бумаги...» [Там же, с. 465]. Сходным оказалось у Достоевского и Шукшина отношение к «народному» слову. Шукшин в рассказе «Артист Федор Грай» подчеркивает неприятие своим героем, сельским кузнецом, представлений о языке «простого» человека, по мнению городского режиссера, обязательно употребляющего словечки типа «чаво», «куды», «евон», «ейный» (II, 76). За век до шукшинского рассказа Достоевский, давая советы девушке-корректору, мечтающей о писательском поприще, спорил с современной литературной традицией: «Никогда народ не говорит так эссенциями. Народ говорит таким же языком, как мы. И может быть, на дюжину слов скажет одно забористое. А у них сплошь вся речь такими словами усеяна. И выходит фальшиво, ни на что не похоже» [Ф.М. Достоевский в воспоминаниях современников, 1990, с. 150]. С проблемой маргинального героя и его сложной самоидентификации связано и широкое введение в контекст творчества Достоевского и Шукшина письменного слова [Рыбальченко, 1998, с. 11-28].

Однако тема истинного, сокровенного в человеке решается в творчестве Достоевского и Шукшина в связи с тем, что их герой, как правило, «homo ludens» (человек играющий), сходно - созданием приемов «провокации», по терминологии М.М. Бахтина. Одна из важных проблем творчества писателей достоверность характеров и обстоятельств, созданная особыми средствами.

Признание Шукшина в статье «Книги выстраивают целые судьбы»: «...мне нравятся крайние ситуации», - является продолжением художественного принципа Достоевского. Ставя своих героев часто в экспериментальные, «пограничные» условия, писатели добиваются последней правды о человеке. Анализируя творчество писателя XX в., Н.Л. Лейдерман пишет об образах «пределов», о том, что жизнь или сам герой «так сказать, “экспериментально” ставит над обрывом, дальше - смерть» [Лейдерман, 1982 б, с. 177].

Отношение к слову, тип героя, средства его изображения определяют во многом и характер метода писателя. Как известно, Достоевский, сопротивляясь искусству слепого копирования действительности, настаивая на акте ее творческого пересоздания, свой метод определил как «фантастический реализм». Исследователи творчества писателя отмечают содержательную «размытость» этого понятия и пытаются более конкретно его определить. В письме к Н.Н. Страхову от 26 февраля (10 марта) 1869 г. Достоевский высказывает свое эстетическое кредо: «У меня свой особенный взгляд на действительность (в искусстве), и то, что большинство называет почти фантастическим и исключительным, то для меня иногда составляет самую сущность действительного» (XXIX (I), 19). 
Однако фантастическое, для Достоевского, не только и не столько факт творческого процесса, это неотъемлемая часть русской жизни: «Порассказать толково то, что мы все, русские, пережили в последние 10 лет в нашем духовном развитии, - да разве не закричат реалисты, что это фантазия! А между тем это исконный, настоящий реализм! (А.Н. Майкову 11(23) декабря 1868 г.) (XXVIII (II), 329).

По мнению исследователей, метод писателя рождается «на пороге»: «Согласно этому взгляду, мир фантастического реализма обнаруживает странное в знакомом, субъективное в объективном, мелодраматическое в банальном, поддерживая рискованное равновесие на границе между одним и другим» (цит. по кн.: [Малькольм, 1998, с. 30]). У многих современников и более поздних критиков возникало чувство нарушенного «равновесия». Часты упреки к прозе Достоевского в безвкусице и разностильности. Уже Н.Н. Страхов в своем печально известном письме к Л. Толстому, отказав Достоевскому в гениальности, подчеркивает эклектику в соединении философски высокого и безвкусно пошлого в его творчестве. В противовес этому он ни на минуту не сомневается в органичности художественного мира своего духовного кумира Л. Толстого, несмотря на его значительную эволюцию, «энергию заблуждений» и отрицания. Эволюция прозы Шукшина - одна из самых интересных и спорных проблем шукшиноведения, достаточно сказать, что поздние произведения писателя поставили в тупик современную критику. Шукшин оказался неорганичен, «разорван» в человеческом и творческом диапазонах. На эту особенность, как на основу поэтики фильма «Калина красная», обратил внимание М. Ульянов: «Калина красная» - странный фильм: если попытаться анализировать ее с точки зрения обычной логики, можно найти много эпизодов, казалось бы, несовместимых. Есть куски очень простые, я бы сказал даже, примитивные. Есть эпизоды, которые у другого художника могли прозвучать сентиментально и фальшиво. Однако все это превратилось в произведение, которое до сих пор живет и так пронзительно действует на миллионы зрителей» [О Шукшине: Экран и жизнь, 1979, с. 312-313].

В этой оценке важно подчеркнуть два аспекта, сближающих не на внешнем, а на глубинном уровне художественные миры писателей. Проза Достоевского и Шукшина не только диалогична в том значении, которое этому термину придавал М.М. Бахтин, подчеркивая новый характер соотношения героя и автора, но и многопафосна и с точки зрения воплощения жанрово-родовых признаков неоднородна. Анализируя творчество автора «Бедных людей», исследователи не раз писали о соотношении реализма и сентиментализма ${ }^{1}$. Сходную черту прозы раннего Шукшина подмечает Л. Аннинский: «Вот удивительная особенность рассказов Шукшина первой половины 60-х годов: в глубинной, скрытой основе они сентиметальны. Несмотря на старательный аскетизм письма (никаких красот, никаких пышных слов!). Сентиментальны - несмотря на суровую фактуру материала» [Аннинский, 1978, с. 116]. Об амбивалентной, серьезно-смеховой природе творчества автора повести-сказки «До третьих петухов» шукшиноведы пишут, опираясь на методологию М.М. Бахтина, тем самым уже констатируя типологическую близость в этом аспекте прозы писателей. Н.Л. Лейдерман, настаивая на жанровой сложности шукшинского рассказа, «описывает» ее в той же парадигме, в которой существует жанрово-видовой синтез прозы Достоевского: «Суть шукшинского рассказа - в принципиальной нерасторжимости комизма и трагизма, драмы и эпоса, которые к тому же существуют в ореоле лирического сопереживания автораповествователя» [Лейдерман, 1982 б, с. 183].

Второй аспект, подчеркнутый М. Ульяновым, заключается в установке шукшинского искусства на коммуникативность. И в этом пункте писатель, опираясь

${ }^{1}$ См. об этом: [Жилякова, 1989]. 
на пушкинскую традицию («...глаголом жги сердца людей»), ближе к позиции Достоевского, чем к «олимпийству» Толстого.

Сложность прозы Достоевского и Шукшина, в горниле которой художественно «переплавляется» различный и неоднородный материал, связан и с ее гипотетичностью, с поставленной задачей - «прорваться в будущую Россию». Поэтому Достоевский сознательно оговаривает «право» писателя на ошибку. Движение к истине для него лежит в возможности ошибаться. Не только герой автора «Преступления и наказания» стремится к «пробе», но, как справедливо отмечает Г.К. Щенников, Достоевский выступает «в защиту писательского права на «пробную», спорную идею, не получившую всеобщего признания, сомнительную для самого художника» [Щенников, 1978, с. 19]. В эпилоге романа «Подросток» Достоевский, как бы устанавливая различия между собой, своим методом и методом Толстого, писал: «Что делать, однако ж, писателю, не желающему писать лишь в одном историческом роде и одержимому тоской по текущему? Угадывать и... ошибаться» (XXXI, 455). Гипотетически созданный художественный мир Достоевского Г.К. Щенников видит в «открыто становящейся мысли, сомневающейся в самой себе, мысли-вопросе», «и это во многом определяет, - по замечанию исследователя, - поэтику» писателя [Щенников, 1978, с. 21]. Человек в художественном мире Достоевского до конца не завершен и не разгадан. «Писатель стремится не к описанию, а к испытанию человеческой натуры» [Там же, с. 29]. Хотя Л. Толстой дает словесную формулу «переворотившегося и только укладывающегося мира», но именно Достоевский в эту эпоху демонстрирует возможность воплощения разных онтологический плоскостей.

Художественный мир Шукшина также во многом гипотетичен: Н.Л. Лейдерман в качестве одной из основных особенностей дара Шукшина назвал «сейсмическую чуткость ко времени» [Лейдерман, 1974, с. 163]. В целом ряде рассказов его герои-мечтатели «моделируют», что могло бы случиться и не случилось («Билетик на второй сеанс», «Миль, пардон, мадам!»). Герой его ранней киноповести «Живет такой парень» вообще живет одновременно в двух мирах - реальном и гипотетическом. Поэтому столь закономерным становится появление в художественном мире Шукшина повести «Точка зрения». Обратим внимание на такую особенность, что само понятие «точка зрения» возникает прежде всего в публицистике Достоевского. К нему же прибегает М.М. Бахтин, характеризуя поэтику автора «Бедных людей»: «...герой интересует Достоевского как особая точка зрения на мир и на самого себя» [Бахтин, 1972, с. 79]. По мнению В.Н. Топорова, особенностью ее воплощения становится тезис «Все что хочешь, может случиться» [Топоров, 1995, с. 196]. Шукшинский рассказ под названием «Версия», в котором воплощается один из возможных вариантов событий. Поэтика названия рассказа «В профиль и анфас» демонстрирует принцип разноракурсности изображения и противостоит тенденции «переть в одну точку». По сути дела, это же положение художественно продемонстрировано в «Точке зрения» Шукшина. Л. Аннинский эту особенность поэтики Шукшина объясняет мучительными противоречиями художественной мысли писателя: «Попробуй тут выпутаться из противоречий, когда вся суть - в противоречиях...» [Аннинский, 1978, с. 245].

Русская философская мысль, обращаясь к анализу творчества Достоевского, не раз подчеркивала, что логика построения его сложного художественного мира покоится на принципе триадности. Эта мысль со всей определенностью выражена В. Ивановым и В.В. Розановым. Последний в триадности видит некий общий закон развития общества: «Но всегда, когда это развитие полно, оно протекает три фазиса: непосредственной первоначальной ясности, падения, возрождения. $<\ldots>$ Если, однако, мы всмотримся в их соотношение, то увидим, что в наблюдаемой действительности средний момент чрезвычайно преобладает над остальными двумя. В истории падение, преступление, грех - это центральное явление, в нем 
бьются бессильно индивидуумы, народы; о нем учит и с ним борется религия, тенью своей оно задевает, наконец, и высокое художество» [О Достоевском. Творчество Достоевского в русской мысли 1881-1931 годов, 1990, с. 66]. Л. Толстой в своем первом произведении, трилогии «тревожных исканий», человеческую жизнь осмысляет как три эпохи развития. И все же в логике развертывания художественного мира двух великих современников, в их взгляде на человеческую жизнь существует принципиальная разница, которую сам Толстой выразил формулой, характеризующей Достоевского: «Он весь борьба». Изображая хаотические состояния, автор «Войны и мира» тяготел к органике, ладу, всегда в своем творчестве показывая, как созидается новый национальный или социальный мир. Достоевского же, по мысли В.Н. Топорова, интересует «временная точка, где силы хаоса, неопределенности, непредсказуемости начинают получать преобладание» [Топоров, 1995, с. 201]. Эта точка «завораживала» и Шукшина. Поэтому мир шукшинской прозы, как у Достоевского, беспокоен и раздражающ, лишен всякой благостности, наполнен преступлениями, нравственными и юридическими, скандалами, парадоксами, посредством которых и может осуществить и индентифицировать себя маргинальная личность. Более того, тенденция эта в художественном мире Шукшина динамическая, усиливающаяся от 1960-х к 1970-м г.

Итак, всем своим обликом и творчеством создавая образ творца и особенности творческого процесса, Шукшин воплощает тот его инвариант, который сложился в национальной традиции. Путь творческого самоопределения Шукшина явно ориентирован на русскую классику, прежде всего связанную с именами Л. Толстого и Достоевского. Однако феномен Шукшина также немыслим без усвоения художественного опыта Пушкина, Гоголя, Лескова, Чехова и др., вклад которых также велик в разработке особой эстетической категории под названием «русский писатель».

\section{Литература}

Аннинский Л.А. Тридцатые - семидесятые. М., 1978.

Бахтин М.М. Проблемы поэтики Достоевского. М., 1972.

Бондарчук С. Первородство // О Шукшине: Экран и жизнь, М., 1979.

Бурсов Б.И. Личность Достоевского. Роман-исследование. Л., 1974.

Ветловская В.Е. Поэтика романа «Братья Карамазовы». Л., 1977.

Геллер Л. Опыт прикладной стилистики. Рассказ В. Шукшина как объект исследования с переменным фокусом расстояния // Wiener Slawistisher Almanach. 1979. № 4.

Горышин Г. Где-нибудь на Руси... // Аврора. 1975. № 6.

Громов Е. Поэтика доброты // О Шукшине: Экран и жизнь. М., 1979.

Достоевский Ф.М. Полное собрание сочинений: В 30 т. Л., 1986. Т. XXIX (I).

Жилякова Э.М. Традиции сентиментализма в творчестве раннего Достоевского. Томск, 1989. 1997.

Заболоцкий А. Шукшин в кадре и за кадром: Записки кинооператора. М.,

Лейдерман Н. Трудная дорога возвышенья // Сибирские огни. 1974. № 8.

Лейдерман Н. Рассказ Василия Шукшина // Н. Лейдерман. Движение времени и законы жанра. Свердловск, 1982 а.

Лейдерман Н. Мироздание по Шукшину // Урал. № 3. 1982 б.

Лихачев Д.С. «Небрежение словом» у Достоевского // Ф.М. Достоевский. Материалы и исследования. Л., 1976. Т.2.

Малькольм В. Джоунс. Достоевский после Бахтина. СПб, 1998.

Мережковский Д.С. Л. Толстой и Достоевский. Вечные спутники. М., 1995.

О Достоевском. Творчество Достоевского в русской мысли 1881-1931 годов. 
M., 1990.

О Шукшине: Экран и жизнь. М., 1979.

Печерская Т.И. Разночинцы шестидесятых годов ХІХ века: феномен самосознания в аспекте филологической герменевтики. Новосибирск, 1999.

Розанов В.В. О писательстве и писателях. М., 1995.

Рыбальченко Т.Л. Текст и письмо в художественном мире В. Шукшина // Творчество В.М. Шукшина как целостность. Барнаул, 1998.

Селезнев Ю. В мире Достоевского. М., 1980.

Топоров В.Н. Миф. Ритуал. Символ. Образ: Исследования в области мифопоэтического. Избранное. М., 1995.

Ф.М. Достоевский в воспоминаниях современников: В 2 т. М., 1990. Т. 2.

Шукшин В. Я пришел дать вам волю. Публицистика. Барнаул, 1991.

Шукшин В.М. Собрание сочинений: В 6-ти т. Т. 2. М., 1992.

Щенников Г.К. Художественное мышление Ф.М. Достоевского. Свердловск, 1978. 